\title{
DIETARY PATTERN OF CHILDREN LIVING IN REGION WITH NON-FERROUS METALS OUTPUT
}

\author{
Baykova D. \\ National Center of Public Health Protection, Sofia \\ Reviewed by: Assoc. Prof. V. Madjova
}

\begin{abstract}
The non-ferrous industrial plant in Plovdiv has been built and functioned for decades. Research show that despite of the fresh and clean air, the soil and vegetation used by people and live-stock are polluted with lead. Children are a risky age group, because of their on-going growth and development, as well as the abilities for adaptation of the child's organism. The aim of this study is to evaluate the nutrient and energy intake and food consumption of children aged 10-14 years, from the village of Kuklen - nearby the non-ferrous industrial plant in Plovdiv. The present epidemiologic survey was conducted in 2003 and included 49 children aged 10-14 years, differentiated by sex - 22 boys and 27 girls. The " 24 hour recall" of food consumption for the previous day method was used. Results show that the average mixed protein (animal and vegetative) intake is 54.1 $\mathrm{g}$ for boys and $45.2 \mathrm{~g}$ for girls and delivers $10 \%$ of the daily food energy $(\mathrm{E} \%)$. Fats provide 38-39 $\mathrm{E} \%$ (Dietary Reference Intakes for Bulgarians, 2005 are 25-30 E\%). Carbohydrates deficit tendency is observed - 51-52 $\mathrm{E} \%$ (recomm. 55-65 E\%). The food energy in boys meets the recommendations, while that for girls covers $84 \%$ of the requirements. All researched children show intake deficiency of vitamin B1, calcium, zinc, iron. The intake of nutrients and energy is relevant to the food consumption. Milk in the daily menu is inadequate: 97.3-95.7 $\mathrm{g}$ (recomm. $400 \mathrm{~g}, 380 \mathrm{~g}$ resp.). The consumption of cheese is also unsatisfactory $21 \mathrm{~g}$ for boys and 12 $\mathrm{g}$ for girls (recomm. $35 \mathrm{~g} / \mathrm{day}$ ). Too low is the consumption of vegetables $-68 \mathrm{~g} / \mathrm{day}$ for boys and $85 \mathrm{~g} / \mathrm{day}$ for girls, which covers $22-30 \%$ of the recommendations. Boys have consumed $226 \mathrm{~g}$ (i.e. $63 \%$ of the recommendations) of fruits, while girls - $205 \mathrm{~g}$ (i.e. $97 \%$ of the recommendations). In conclusion, various suggestions for the development of a complex interventional program are made in order to diminish the risk of potential chemical food pollutions and to balance the food intake.
\end{abstract}

Key words: children, 10-14 years, intake, nutrients, energy, food consumption, ecologically risky region

The non-ferrous industrial plant in Plovdiv has been built and functioned for decades. It is situated in an area of well-developed and active agriculture and stock-breeding. Research show that despite of the clean air, soil and vegetation used by people and live-stock are polluted with lead $(1,2)$. There are objective health risk circumstances for the population which inhabits the district south of the city of Plovdiv (incl. the village of Kuklen) and uses the land for agriculture and stock-breeding, respectively - for the regionally consumed food of animal and vegetative origin (3).

Children are age group at risk, because toxic effects caused by lead upon the central nervous system, hemopoesis, renal function, etc. can be manifested in much lower tissue concentrations in children, compared to adults. References show that there is a sex differentiation of the health risk. Boys aged 10-14 years are at a higher risk compared to girls of the same age and there is a tendency to decrease this distinction with age progression.

Address for correspondence:

D. Baykova; National Center of Public Health Protection, Sofia

e-mail: d.baykova@abv.bg
The aim of this study is to evaluate the nutrient and energy intake and food consumption of children aged 10-14 years, from the village of Kuklen - nearby the non-ferrous industrial plant in Plovdiv.

\section{MATERIAL AND METHODS}

The present epidemiologic survey was conducted in May, 2003 and included 49 children aged 10-14 years, differentiated by sex - 22 boys and 27 girls, inhabiting an ecologically risky area - the village of Kuklen on the south of the city of Plovdiv. This study is a part of a complex investigation of the health risk for the same population (3).

The "24 hour recall" of food consumption for the previous workday method was used. Fotoalbums for evaluation of the consumed food were used for precise collection of the information. Data analysis was performed by computer software for evaluation of the food intake, while statistical analysis - with SPSS-10 software. 
Baykova D.

Evaluations were made in accordance with the Dietary Reference Intakes for Bulgarians, 2005 (4) as well as national and international Recommendations for healthy nutrition of children (Dietary Guidelines) (5-7).

\section{RESULTS}

Results show that the average protein intake (table 1) is $54.1 \mathrm{~g}$ for boys aged 10-14 years and $45.2 \mathrm{~g}$ for girls and delivers $10.3 \%$ of the daily food energy (E\%). These values comply with the reference dietary intake (RDI) of protein $43 \mathrm{~g}$ for boys and $42 \mathrm{~g}$ for girls and $10-15 \mathrm{E} \%$. (4). In regard to mean-group values the protein intake is satisfactory. Analysis on the individual level shows that medians are close to the mean values. Bearing in mind the fact that in our nutritional pattern only half of the consumed protein is of high biological value, it is clear that there is a risk of deficiency in terms of high biological value protein intake. In all of researched children there is an overconsumption of fats (table 1), which deliver $38-39 \%$ of the total daily food energy (E\%), while the recommendations are $25-30 \mathrm{E} \%$ (4).

Table 1. Average nutrients and energy daily intake of boys and girls aged 10-14 years from the village of Kuklen

\begin{tabular}{||c|c|c|c|c|c|c||}
\hline & \multicolumn{3}{|c|}{ Boys } & \multicolumn{3}{c||}{ Girls } \\
\cline { 2 - 7 } & Mean & SD & Median & Mean & SD & Median \\
\hline $\begin{array}{c}\text { Protein } \\
\text { g) } \\
\text { Total } \\
\text { amount }\end{array}$ & 54.1 & 20.3 & 54.5 & 45.1 & 18.9 & 45.6 \\
\hline E\% & 10.3 & 2.9 & 9.5 & 9.9 & 2.4 & 9.7 \\
\hline Fats (g) & 89.7 & 34.3 & 81.2 & 77.6 & 29.7 & 74.9 \\
\hline E\% & 37.9 & 5.6 & 38.6 & 38.9 & 6.9 & 38.9 \\
\hline $\begin{array}{c}\text { Carbo- } \\
\text { hydra- } \\
\text { tes (g) }\end{array}$ & 272.6 & 91.1 & 251.6 & 226.9 & 74.9 & 205.8 \\
\hline E\% & 51.7 & 5.9 & 52.5 & 51.2 & 7.6 & 51.6 \\
\hline Energy & 2114.5 & 677.9 & 1930.6 & 1787.1 & 550.1 & 1825.8 \\
\hline \hline
\end{tabular}

A trend in deficiency of the carbohydrates intake is observed - $51-51 \mathrm{E} \%$ for all boys and girls (table 1), while the recommendations stand for 55-65 $\mathrm{E} \%$ (4).

The energy of the consumed food is $2114.5 \mathrm{kcal}$ for boys and $1787.1 \mathrm{kcal}$ for girls with energy requirements of 2610 $\mathrm{kcal} /$ day for boys and $2138 \mathrm{kcal} /$ day for girls aged 10-14 years with moderate physical activity. It is clear that the real energy food intake of boys covers $84 \%$ of the recommendations (4). Medians do not differ substantially among the mean-group values.

RDI for vitamin B1 is $1.2 \mathrm{mg}$ for boys, while the established consumption is $0.8 \mathrm{mg}$ (table 2). For girls the intake is $1.1 \mathrm{mg}$ recommended consumption and $0.6 \mathrm{mg}$ real consumption. Boys consume $65 \%$, while girls - $55 \%$ of the recommended amount of vitamin B1.

The average intake of vitamin B2 (table 2) is $1.2 \mathrm{mg}$ for boys and $1.0 \mathrm{mg}$ for girls, with RDI - $1.3 \mathrm{mg}$ and $1.0 \mathrm{mg}$ resp. Vitamin C (table 2) with RDI of $45 \mathrm{mg}$ for both boys and girls is consumed in amounts of $74 \mathrm{mg}$ and clearly complies with the recommendations (PR, 2005).

Table 2. Average vitamins and minerals daily intake of boys and girls aged 10-14 years from the village of Kuklen

\begin{tabular}{||c|c|c|c|c|c|c||}
\hline \hline & \multicolumn{3}{|c|}{ Boys } & \multicolumn{3}{c||}{ Girls } \\
\cline { 2 - 7 } & Mean & SD & $\begin{array}{c}\text { Media } \\
\mathbf{n}\end{array}$ & Mean & SD & $\begin{array}{c}\text { Media } \\
\text { n }\end{array}$ \\
\hline $\begin{array}{c}\text { Vitamin } \\
\text { B1 (mg) }\end{array}$ & 0.8 & 0.5 & 0.6 & 0.6 & 0.3 & 0.6 \\
\hline $\begin{array}{c}\text { Vitamin } \\
\text { B2 (mg) }\end{array}$ & 1.2 & 0.8 & 0.9 & 1.0 & 0.5 & 0.9 \\
\hline $\begin{array}{c}\text { Vitamin } \\
\text { C (mg) }\end{array}$ & 74.0 & 67.7 & 63.2 & 73.5 & 51.4 & 68.3 \\
\hline $\begin{array}{c}\text { Vitamin } \\
\text { E (mg) } \alpha \\
\text { TE }\end{array}$ & 17.6 & 9.6 & 14.4 & 18.9 & 9.5 & 16.3 \\
\hline $\begin{array}{c}\text { Vitamin } \\
\text { A (mcg) } \\
\text { PE }\end{array}$ & 593.1 & 489.1 & 397.7 & 810.4 & 1461.5 & 351.7 \\
\hline $\begin{array}{c}\text { Calcium } \\
(\mathrm{mg})\end{array}$ & 450.7 & 247.9 & 397.3 & 397.9 & 179.4 & 366.8 \\
\hline $\begin{array}{c}\text { Zinc } \\
(\mathrm{mg})\end{array}$ & 5.8 & 2.3 & 5.3 & 5.5 & 2.9 & 5.7 \\
\hline $\begin{array}{c}\text { Iron } \\
(\mathrm{mg})\end{array}$ & 8.8 & 5.5 & 6.5 & 7.3 & 3.5 & 6.7 \\
\hline \hline
\end{tabular}

The intake of the fat-soluble vitamin E (table 2) also covers the Dietary Reference Intakes for Bulgarians, 2005 (4) for both sex groups - boys and girls: 18-19/day mg alfa-TE with recommended for $10 \mathrm{mg} /$ day alfa TE.

Vitamin A (table 2) is consumed in average amount of 592 mcg RE for boys and $810 \mathrm{mcg}$ RE for girls (RDI - $600 \mathrm{mcg}$ PE for both sexes).

The average intake of calcium (table 2) is unsatisfactory. RDI stand for $1300 \mathrm{mg} / \mathrm{day}$, while the real consumption is $451 \mathrm{mg}$ for boys and $398 \mathrm{mg}$ for girls. On individual level all of the studied school children $(100 \%)$ are at risk of calcium deficiency because they consume lower quantities of calcium in relation to the RDI shown in Dietary Reference Intakes for Bulgarians, 2005 (4).

The average zinc consumption (table 2) for all the boys and girls of the village of Kuklen is lower than RDI $(9.0 \mathrm{mg}$ for boys and $8.0 \mathrm{mg}$ for girls). The real consumption of zinc is $5.8 \mathrm{mg} /$ day for boys and $5.6 \mathrm{mg} /$ day for girls respectively. Iron intake is low (table 2) in both subgroups - boys and girls. With recommendations for $11 \mathrm{mg}$ for boys and $15 \mathrm{mg}$ 
Dietary pattern of children living in region with non-ferrous metals output

for girls, the average iron intake per day is $9 \mathrm{mg}$ for boys, which is $82 \%$ of RDI and $7.3 \mathrm{mg}$ for girls - $49 \%$ of RDI. (recomm. for $380 \mathrm{~g}$ ) (5). Cheese is also insufficient in the children's daily menu $-21 \mathrm{~g}$ for boys and $12 \mathrm{~g}$ for girls, with recommendations for $35 \mathrm{~g} /$ day for both (5).

Table 3. Average daily food consumption of boys and girls per day aged 10-14 years from the village of Kuklen

\begin{tabular}{|c|c|c|c|c|c|c|}
\hline Food group (g) & Mean & $\begin{array}{l}\text { Standard } \\
\text { Deviation }\end{array}$ & Median & Mean & $\begin{array}{l}\text { Standard } \\
\text { Deviation }\end{array}$ & Median \\
\hline Milk and milk products & 97.3 & 133.5 & 39.2 & 95.7 & 107.1 & 73.3 \\
\hline Milk & 76.1 & 127.5 & 11.4 & 83.2 & 102.8 & 33.3 \\
\hline Meat and meat products & 65.9 & 70.6 & 45.0 & 48.6 & 64.1 & 30.0 \\
\hline Meat & 41.6 & 62.9 & 0.0 & 36.1 & 55.4 & 0.0 \\
\hline Meat products & 24.4 & 40.2 & 0.0 & 8.1 & 13.3 & 0.0 \\
\hline Fish and other seafood & 5.5 & 25.8 & 0.0 & 0.0 & 0.0 & 0.0 \\
\hline Eggs & 8.6 & 14.3 & 0.0 & 13.2 & 31.2 & 0.0 \\
\hline Fats & 30.5 & 19.9 & 25.5 & 29.0 & 15.4 & 26.7 \\
\hline Milk oils & 9.1 & 13.5 & 7.0 & 4.9 & 7.5 & 0.0 \\
\hline Plant oils & 18.9 & 13.7 & 14.5 & 21.3 & 11.6 & 22.5 \\
\hline Bread and pastry & 281.1 & 146.7 & 257.2 & 210.4 & 89.7 & 197.3 \\
\hline Bread & 141.9 & 68.6 & 150.0 & 110.4 & 51.1 & 100.0 \\
\hline Rice & 5.1 & 10.8 & 0.0 & 8.2 & 15.9 & 0.0 \\
\hline Potatoes & 121.2 & 173.8 & 0.0 & 144.6 & 168.4 & 52.5 \\
\hline Beans & 12.1 & 21.2 & 0.0 & 11.0 & 33.1 & 0.0 \\
\hline Vegetables & 67.6 & 52.3 & 66.9 & 84.9 & 70.1 & 67.7 \\
\hline Fresh vegetables & 5.4 & 15.2 & 0.0 & 5.4 & 14.9 & 0.0 \\
\hline Fruits & 225.8 & 259.3 & 125.0 & 205.1 & 138.6 & 200.0 \\
\hline Fresh fruits & 28.9 & 53.1 & 0.0 & 24.1 & 41.9 & 0.0 \\
\hline Nuts and seeds & 0.9 & 2.3 & 0.0 & 2.0 & 7.6 & 0.0 \\
\hline Sugar and sugar products & 62.4 & 55.7 & 48.0 & 44.7 & 46.0 & 25.0 \\
\hline Sugar & 12.3 & 23.2 & 0.0 & 5.3 & 18.7 & 0.0 \\
\hline Sugar products & 50.1 & 48.6 & 39.0 & 39.3 & 43.9 & 25.0 \\
\hline Honey & 1.1 & 5.3 & 0.0 & 0.0 & 0.0 & 0.0 \\
\hline Spices & 3.1 & 2.6 & 3.2 & 3.9 & 3.5 & 2.8 \\
\hline Alcohol-free beverages & 50.0 & 84.5 & 0.0 & 81.1 & 119.1 & 0.0 \\
\hline Tea & 27.3 & 71.9 & 0.0 & 11.1 & 40.0 & 0.0 \\
\hline Salt & 1.3 & 0.9 & 1.0 & 1.5 & 0.1 & 1.0 \\
\hline
\end{tabular}

These characteristics of the energy and nutrient intake correlate with the average food and food groups' consumption (table 3).

The consumption of milk is unsatisfactory (4 times lower than the recommendations) in all researched boys and girls - $97.3 \mathrm{~g}$ for boys (recomm. for $400 \mathrm{~g}$ ) and $95.7 \mathrm{~g}$ for girls
Traditionally low is the daily fish consumption. None of the girls have consumed any fish during the course of the study, while the boys have consumed $5.5 \mathrm{~g}$ (recommendations for $24 \mathrm{~g} /$ day net weight) (5).

The consumption of eggs in the daily menu of the boys is $8.6 \mathrm{~g}-41 \%$ of the recommendations, as of the girls $-13.2 \mathrm{~g}$ 
Baykova D.

- $88 \%$ of the recommendations (which are $21 \mathrm{~g}$, resp. 15 $\mathrm{g}$ /day net weight for boys and girls aged 10-14 years).

The consumption of bread meets $55 \%$ of the recommendations for both subgroups.

The daily consumption of rice is insufficient in boys and girls and is in the region of $42-70 \%$ of the recommendations.

Boys and girls consume potatoes in amounts of 121-145 $\mathrm{g} /$ day, which correspond with the recommendations (5-7). The consumption of leguminous foods also meets the recommended values.

The consumption of vegetables is too low - $68 \mathrm{~g} /$ day for boys and $85 \mathrm{~g}$ /day for girls, with recommendations for net weight of $302 \mathrm{~g}$ and $288 \mathrm{~g}$, resp., which is only $22-30 \%$ of the requirements.

The daily intake of fruits appears to be better. With recommended amount of $361 \mathrm{~g}$ net weight per day, the real fruit consumption of boys is $226 \mathrm{~g}$ (i.e. - 63\%). For the girls recommendations are $212 \mathrm{~g}$ net weight, and the real consumption - $205 \mathrm{~g}$ ( $97 \%$ of the recomm.).

\section{SUMMARY AND DISCUSSION}

The food and energy intake of children aged 10-14 years and living in an ecologically risk area - nearby the non-ferrous industrial plant in Plovdiv is a disbalanced one. The evaluation of protein intake through food consumption analysis shows that the presence of milk and milk products, eggs fish in the daily menu of children from the village of Kuklen is insufficient. These are the products with balanced essential amino acid formula and they play important biological role in the processes of tissue protein synthesis of the growing boys and girls - and in particular in the synthesis of immune factors. The recommendations for nutrition in respect of elevated toxic agents' concentration in the environment and foods are based on a higher intake of proteins with high biological value, vitamins and minerals and on a well-balanced fat, carbohydrate and energy intake. These are the exact recommendations which have not been fulfilled by the real nutritional pattern of Kuklen school children and it does not meet the medical-biological requirements of the children's organism and experts' references $(6,8,9)$. The intake of vitamin B1, calcium, zinc and iron is deficient. The low micronutrient intake correlates with the insufficient consumption of bread and cereals (rice) which are a major source of vitamin B1 in our national nutrition. The dangerously short supply of iron is exposed by the analysis of the consumption of meat (lower than the recommendations), fish (almost absent), and eggs. Polysaccharides (complex carbohydrates) have been consumed mainly through potatoes and leguminous foods. The unsatisfactory amount of calcium in the children's nutrition of this area can be explained with low consumption of milk and milk products. There is a high risk for various health problems $(9,10)$. These include: immune deficiency, iron-deficiency conditions and their complications in life, and risk for reproductive disorders with advancement of age.

\section{CONCLUSIONS}

1. The average mixed protein intake (of animal and plant origin) is $54.1 \mathrm{~g}$ for boys and $45.2 \mathrm{~g}$ for girls and is a source of $10.3 \mathrm{E} \%$. Fats deliver $38-39 \%$ of the total daily food energy (E\%), with recommendations for $25-30 \%$. A trend for deficiency in carbohydrate intake is observed - 51-52 $\mathrm{E} \%$ for all boys and girls, with recommendations for 55-65 E\%. Food energy for boys meets the recommended ones, while for girls they cover $84 \%$ of the requirements.

2. The average intake of calcium is unsatisfactory - 451 $\mathrm{mg}$ for boys and $398 \mathrm{mg}$ for girls (recomm. 1300 $\mathrm{mg}$ /day). Boys consume $65 \%$ and girls - $55 \%$ of the recommended dietary intake (RDI) of vitamin B1. The average daily intake of iron is $9 \mathrm{mg}$ for boys, which is $82 \%$ of RDI and $7.3 \mathrm{mg}$ for girls - $49 \%$ of RDI.

3. Both boys and girls have consumed insufficient amount of milk - 97.3-95.7 $\mathrm{g}$ (recomm. 400-380 g, resp.). The consumption of cheese is low - $21 \mathrm{~g}$ for boys and $12 \mathrm{~g}$ for girls, with recomm. for $35 \mathrm{~g} /$ day. The consumption of eggs is deficient - $42-70 \%$ of the recommendations, as is the consumption of fish, bread, rice $(55 \%$ of the recommendations).

4. The consumption of vegetables is too low $-68 \mathrm{~g} /$ day for boys and $85 \mathrm{~g}$ /day for girls, which covers $22-30 \%$ of the recommendations.

5. Boys have consumed 226 g (i.e. 63\%) of the recommended amount of fruits, and girls - 205g ( $97 \%$ of the recomm.).

The discovered disbalances in the nutritional pattern of children from the ecologically risk areas of the non-ferrous industrial plant of Plovdiv demand the development of a complex interventional program, which is aimed both at the decrease of eventual chemical local food pollutants and correction of the food intake (11-13). Considering the potential serious health risks, a need for specially designed state food policy for children and adolescents is also apparent, which will specifically engage every institutions responsible for children's nutrition and for promoting their knowledge of the problems of healthy nutrition.

\section{REFERENCES}

1. Staykova J, Tarnovska T. Health status of children living in the area of lead-zink industry. Book of abstract, Scientific conference, St. Zagora, 2004, 173-176.

2. Nikiforov B, Antova T, Staykova J. Health indicators for assessment of the effect of environment on the population. J.of environmental protection and ecology 2005; 6(4):802-806.

3. Epidemiological Studies on Assessment of Health Risk and its Control in Ecollogically Pollute Regions in Bulgaria, by Order of Ministry of Health,(Ed.B. Nikiforov) RD 09-369/25.10.2002

4. Dietary Reference Intakes for Bulgarians, 2005 - Official gazette, issue 63, 2005. 
Dietary pattern of children living in region with non-ferrous metals output

5. Methodological guide for application of Dietary Reference Intakes for Bulgarians, MH,1998

6. Dietary Guidelines for healthy nutrition of school children aged 7-19 years in Bulgaria - MH, NCPHP, Bulvest, S, 2008,38

7. WHO, Regional Office for Europe, CINDI Dietary Guide (EUR/OO/5018028), 2000

8. Baykova D. Dietary Intake Characteristics And Anthropometric Nutritional Status Of Children And Adolescents During The Transition Period. In: (Ed. Popov B.). Science of Nutrition as a Protector of $\mathrm{Hu}$ man Health, IK "Blenda", 2004, p 96-101
9. WHO/FAO Expert Consultation. Diet, Nutrition and the Prevention of Chronic Diseases. WHO TRS 916. WHO, Geneva, 2003; 34-3

10. Lambert J, Agostoni C, Elmadfa I, et al. Dietary intake and nutritional status of children and adolescents in Europe, BJN, 2004; 92,(1).2: S147-S211

11. National plan of action Foods And Nutrition 2005-2010,MH, 2006

12. European Strategy for Child and Adolescent Health and Development, WHO Regional Office for Europe, 2005

13. European Action Plan for Food and Nutrition Policy 2007-2012, WHO Regional Office for Europe, 2008 